\title{
What are the Essentials for Community Resilience against Recurring Floods?
}

\author{
Harkunti Pertiwi Rahayu ${ }^{\text {a, }}$, Devina Khoirunnisa ${ }^{\text {a }}$, Deri Syaeful Rohman ${ }^{\text {a }}$, Andi Idham Asman ${ }^{\text {a, }}$ \\ Benedictus Kombaitan $^{\text {a }}$ \\ ${ }^{a}$ Department of Urban and Regional Planning, Institut Teknologi Bandung, Bandung, 40132, Indonesia \\ Corresponding author: *harkunti@pl.itb.ac.id
}

\begin{abstract}
Flood has become the recurring and prominent disaster risk in Indonesia's Capital Region, Jakarta. Heavy rain intensity merged with urban development issues, including urbanization, land subsidence, and water recharge land conversion causes the widening of flooded areas across Jakarta, Bekasi, Tangerang, and Depok. This causes the need for communities at risk to catch up in their institutional and non-institutional capacity to cope with the flood impacts during the rainy season each year. Thus, communities have learned to depend less on institutional capacities and invest in community resilience instead. This study assesses the community flood resilience factors found in current literature and compares them with the findings from community cases Kampung Melayu and Kebon Baru Urban Communities (Kelurahan) in Jakarta. This paper aims to validate and contrasts the key contributing factors to community resilience based on the literature and findings from flood-prone communities in two urban communities in Jakarta. Community resilience data were collected through town watching, interviews, and community engagement observation in two months. The study found that prominent factors for resilience within the community in these case study locations are leadership, activism, and volunteerism through periodic capacity building and community engagement activities across all sectors. Moreover, there is a need for mutual acknowledgment between community grassroots organizations and government authorities to enhance and accelerate resilience building.
\end{abstract}

Keywords - Ciliwung River Basin; community resilience; urban neighborhoods; flood risk management; hydro-meteorological hazard.

\section{INTRODUCTION}

Flood has been a recurring threat in many urban areas across the world. As Indonesia's capital city, Jakarta has been suffering from yearly floods for more than two decades. Moreover, there has been an increase in the frequency of occurrence and expansion of inundated areas year by year [1]. This is due to the impacts of climate change, which affects the weather pattern and rainfall extremes [2], amplified by several other flood drivers, including the conversion of conservation areas into built land use [1], [3], inadequate drainage capacity [4], [5], and land subsidence [6]. To top off these physical factors, ineffective river management due to transboundary barriers and multi-level governance could not cope with the complexity of the urban issues resulting in the increasing risk of flood in Jakarta [7]-[9].

Researchers in multidisciplinary fields are working on finding solutions to flood problems. Although some improvements have been made, they could not keep up with the events' worsening pace [10], especially in the last ten years. This is shown by the drastic increase in flooded areas in 2012, 2018, and 2020 flood events compared to the previous decade (Fig. 2).

In the past several years, communities prone to floods had to accept, adapt, and live with flood [11]. This showcases the increasing need for resilience building in addition to having adequate risk management in place.

Researchers have been promoting resilience-building with the increasing risk of climate disasters [12], [13]. In order to suit the dynamic nature of climate disasters resilience requires constant adapting and transforming to changes [14]. Because climate change impacts regions differently, Kwok et al. [15] argue that resilience can be observed best in small units, such as at the neighborhood level. This method of assessing urban resilience in the community is highly needed, especially in enormous, diverse urban areas such as Jakarta.

Previous research studies showcased that resilience aspects, including psychological, cultural, political, and institutional 
elements, are better understood in small communities than in a larger study area. Additionally, there is a strong indication that resilience factors vary by types of risks and community characteristics.

This paper sets off the navigation for a 3-year research project titled "Case for Support: Mitigating Hydrometeorological Hazard Impacts through Transboundary River Management in the Ciliwung River Basin," which focuses on developing resilient community systems for Integrated Flood Risk Early Warning System and End-to-end Flood Risk Management. The community resilience assessment supports the project by identifying imminent qualitative factors underlying the problems and solutions for Jakarta's flood risk management.

In this study, key contributing factors to community resilience are identified from the literature. These factors will then be used as a base framework for Jakarta's Urban Community (Kelurahan) level survey. Finally, the survey provides validation and shows contrasting aspects specific to the case of urban floods in Jakarta. The main research questions of this paper are:

- What are the key factors to building resilient communities in the case of urban floods?

- How can these factors be observed and assessed within the community at the smallest level?

- What are the similar and contrasting key resilience factors specific to the case study compared to the factors identified in the literature?

The paper describes a village-level study on community resilience in the case of urban floods in Jakarta. The aim is to validate and contrasts the key contributing factors to community resilience identified in literature with the findings from selected flood-threatened villages (Urban Community/Kelurahan) in Jakarta. The objectives of this study are as follows:

- Identify the literature on what community resilience factors in the case of urban floods are.

- Conduct a village-level survey that accommodates understanding and compares the identified resilience factors for floods in Jakarta, Indonesia.

\section{MAterials AND MethoD}

\section{A. Related Works}

Researchers have thought out resilience for several decades, such as environmental hazards, climate change adaptation, business continuity, and disaster risk management. As defined by Patton [16], disaster resilience refers to the condition of being able to resist and bounce back faster after a disaster event. The term "resilience" has been included in the SDGs and adapted in many countries. However, most conversation on resilience happens in high-level actors such as international and national organizations. The term resilience itself is not well pronounced at community levels. However, there are traits embedded within the communities which attribute to stronger resilience [15]. Thus, identifying community aspects contributing to resilience is in high demand, especially at the smallest community level.

According to Field et al. [17], the gap between the visioning of resilience and its implementation in the community level lies in translating the formal visions and documents into practiced actions and activities at the smallest level, individual, family, and community. While sometimes resilience indicators can be very vague, it is still necessary to align common goals actions in multiple levels - national, local, and community levels.

The floods are of both fluvial and coastal origin and are worsening due to many drivers, including physical and socioeconomic, and due to climate change impacts. Physical drivers include land subsidence, drainage, and storage capacity in Jakarta's rivers and canals due to being clogged by waste and sediments eroded from upstream and climate change. Socio-economic drivers include a rapidly growing population and land-use change, causing economic assets to grow in potentially flood-prone areas. Global climate variabilities have proven to increase the frequency and severity of extreme weather events [8].

In common with many other countries, flood management in Jakarta has traditionally focused on structural protection measures to lower the probability of flood hazards through dikes and levees [18]. However, recent years have seen a shift towards a flood-risk management-based approach in Jakarta [19]. In this approach, flood risk management addresses exposure and vulnerability in combination with traditional hazard-reducing measures. Recent examples include the Garuda Project as part of the National Capital Integrated Coastal Development project and the Jakarta Spatial Plan 2030 that discusses the integration of flood control and zoning with spatial planning measures. The last ten years have seen flood risk embedded within relevant legislation, including Law No. 24/2007 and Government Regulation No. 21/2008. It is also addressed in the National Action Plan for Disaster Risk Reduction 2010-2012 at the country scale. Despite some progress with these and other measures, local actors recognize that they are not sufficient to tackle the growing flood threat [20].

\section{B. Proposed Framework}

Flood resilience is the ability to adapt to flood events and recover from them afterwards [21]. Meanwhile, Pelling et al. [22] emphasize the need to include transformative adaptation in the aftermath of each flood event. This means there should be a constant improvement of resiliency level as periods of floods occur in the affected areas.

Resilience makes possible an adaptive state of risk absorption rather than the more "static" traditional disaster risk reduction [23]. Therefore, not only adequate risk management but adaptive capacity is highly expected in resilient communities.

Adaptive capacity is a variable within vulnerability that withstands exposure and sensitivity from a certain environmental hazard [24], [25]. Multiple studies on measurable features of community resilience have been published, promoting embedded social capitals such as network connectedness and community diversity as main factors for disaster resiliency [21], [26], [27].

According to White et al. [23], adequate disaster risk management should provide prerequisite disaster resilience. Consequently, collective hazard awareness and perception could be one measure of disaster resilience. 
Dwirahmadi et al. [21] point out other resources such as funding and structural mitigation as other factors that promote flood resilience. Flood resilience requires both material and non-material resources. Material resources such as funding, flood emergency aid and equipment, and infrastructure are crucial for the successful implementation of disaster management plans. In contrast, non-material resources such as risk and hazard information and capacity training are essential for planning [27]. Fig. 1 summarizes the driving factors for flood risk community resilience.

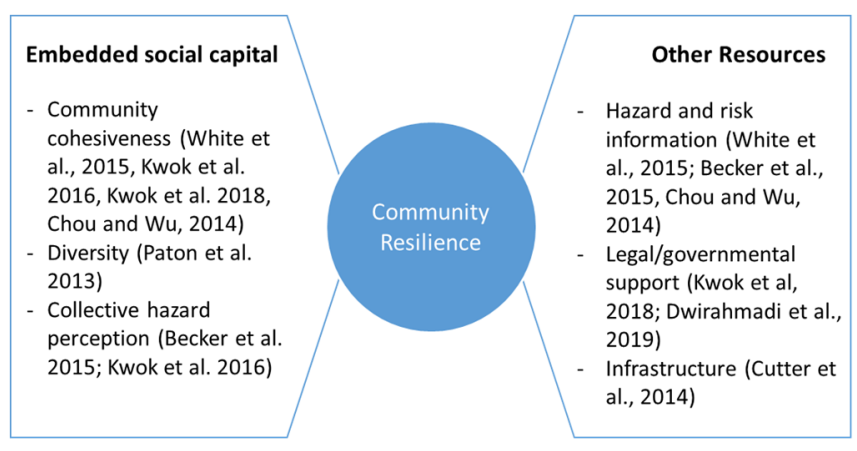

Fig. 1 Flood risk community resilience framework

\section{Data Collection and Analysis Methods}

This study confirms the compatibility of community resilience factors (as summarized in Fig. 1) to the study case of urban floods in Jakarta in Kampung Melayu and Kebon Baru urban neighborhoods. The selection of these villages as case studies is based on the flood frequency map (Fig. 2). In this study, the two villages are selected from several frequently flooded villages in Jakarta using Explanatory Spatial Data Analysis (ESDA) in GEODA.

The selection of Kebon Baru and Kampung Melayu Village as study areas was determined based on cluster analysis of flood-affected regions from 2013, 2014, 2015, 2017 , to 2018. The method used to determine the study area was using the Local G* Cluster Map Analysis technique with the Explanatory Spatial Data Analysis (ESDA) approach from GEODA. The analysis was run upon flood frequency data from 2013 to 2018 obtained from the DKI Jakarta Provincial Disaster Management Agency (BPBD). The data is used to determine the study area within a cluster of areas that are often affected by flooding. Based on the analysis of the Local $G^{*}$ Cluster Map Analysis, it was found that some areas in Kebon Baru and Kampung Melayu are the highest clustered areas (Fig. 2).

Figure 2-A shows the distribution of cluster of flood frequency area in 2013, 2-B shows the distribution of cluster of flood frequency area in 2014, as such, 2-C in 2015, 2-D in 2017 and 2-E in 2018. The results of this analysis are then used as a basis for determining the study area. From this analysis, Kebon Baru and Kampung Melayu village have the highest frequency of returning floods. Therefore, the two study areas for this study are Kebon Baru and Kampung Melayu.

Kebon Baru lays west of the Ciliwung River, while Kampung Melayu in the east of the Ciliwung River. The two urban villages administratively belong to different sub-district and different municipalities. Kebon Baru is in the Tebet subdistrict of South Jakarta, while Kampung Melayu is in
Jatinegara sub-district of East Jakarta. Approximately $62 \%$ of this area is inundated by yearly floods, causing high population exposure [4]. The two villages have similarities in socio-economic characteristics despite the different administrative municipalities.

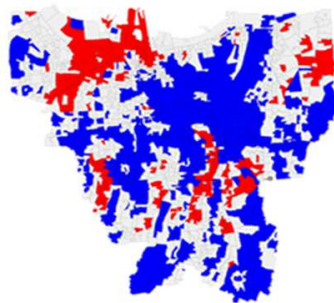

A. Flood in 2013

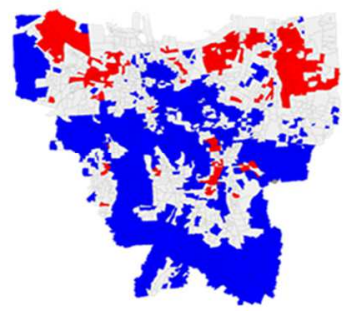

C. Flood in 2015

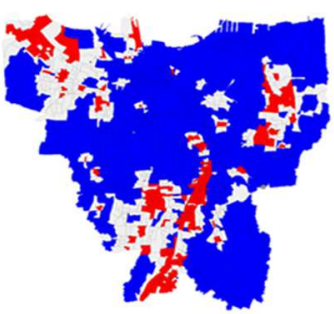

E. Flood in 2018

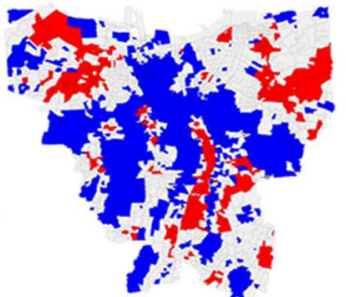

B. Flood in 2014

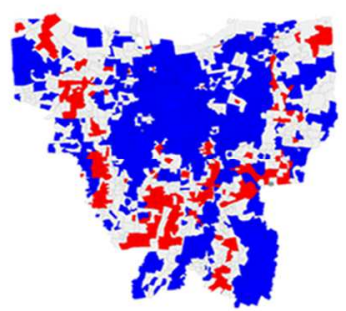

D. Flood in 2017

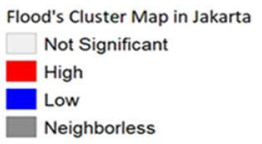

Fig. 2 Local $\mathrm{G} *$ Cluster Map of flood frequency in the DKI Jakarta area spatial-temporally

The study relies mainly on qualitative data; results are derived from interpretations using grounded theory. The use of grounded theory is most suitable for this study to allow inputs from multiple forms of data. In order to provide a comprehensive information of the study area, several methods are used in the data collection, which include town-watching, Focus Group Discussion (FGD), observation (passive participation) in community drills, and interviews.

Town-watching in the Kampung Melayu and Kebon Baru area entails identifying physical vulnerability and capacity from floods. This includes measuring main access roads, geotagging critical facilities, potential assembly points, and flood evacuation shelters. The town-watching survey was conducted on November 6th to November 15th, 2019 which was the starting of the wet season in Jakarta Province.
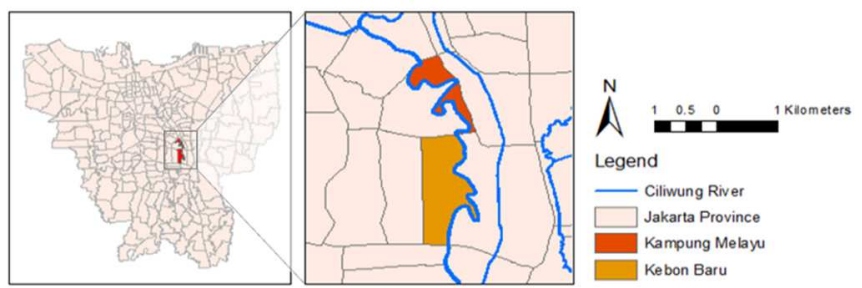

Fig. 3 Survey map of Kampung Melayu and Kebon Baru 
In November 2019, the survey team participated a focus group discussion (FGD) conducted by Jakarta Provincial Disaster Agency (BPBD DKI Jakarta in Bahasa). The main topic of the FGD was to measure community preparedness against the 2020 flood. This FGD was an extension of the national program, Disaster Resilient Villages (in Bahasa Desa Tangguh Bencana or Destana). On the day of the FGD, a tabletop exercise, flood simulation, and emergency response drill were conducted. Observation from the FGD also supplied some information as part of this study. These exercises aimed to test out the village level contingency plan, which involves formal community organizations such as Family Welfare Movement (Pemberdayaan Kesejahteraan Keluarga, PKK), Neighborhood Unit (RW/RT), Youth Organization (Karang Taruna), Urban Communities (Kelurahan). Three main sectors were tested: search and rescue, logistics, and education (such as emergency schools).

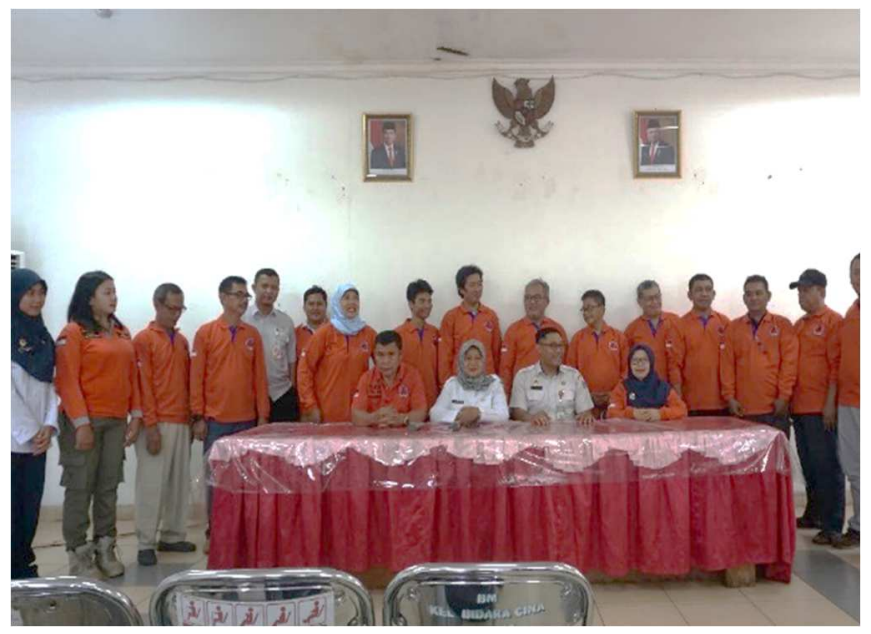

Fig. 4 Community engagement activity

Lastly, semi-structured interview data were collected from key actors. The interviewees consist of local champions in Kampung Melayu and Kebon Baru village called "Mat Peci" (Komunitas Masyarakat Peduli Ciliwung), a volunteer-based organization that focuses on environmental and flood issues in the Ciliwung River, and village officers in Kampung Melayu and Kebon Baru. The flood risk management checklist was assessed using the interview data.

The flood risk management checklists were created from indicators mentioned in the Sendai Framework for Disaster Risk Reduction (SFDRR), New Urban Agenda, and National Action Plan for Climate Change Adaptation (in Bahasa: Rencana Aksi Nasional Adaptasi Perubahan Iklim, RANAPI), which correspond to flood hazard. Author judgment is introduced to simplify and suit the risk characteristic of the two studied areas.

\section{RESULTS AND DISCUSSIONS}

\section{A. Flood Risk Management Assessment}

Based on the data collection, there is a similar flood risk management performance level in Kebon Baru and Kampung Melayu village. Both are very strong in emergency response and early warning system aspects, but very weak in risk assessment.
TABLE I

FLOOD RISK MANAGEMENT CHECKLIST

\begin{tabular}{|c|c|}
\hline Element & Indicator \\
\hline \multirow{6}{*}{$\begin{array}{l}\text { Risk } \\
\text { assessment }\end{array}$} & Existing flood risk assessment \\
\hline & Existing flood hazard map and assessment \\
\hline & $\begin{array}{l}\text { Existing flood vulnerability map and } \\
\text { assessment }\end{array}$ \\
\hline & Existing flood evacuation map and assessment \\
\hline & $\begin{array}{l}\text { Periodic information updating (map, } \\
\text { assessment, etc) }\end{array}$ \\
\hline & Public information accessibility \\
\hline \multirow[t]{7}{*}{ Prevention } & Existing functional flood-pump \\
\hline & $\begin{array}{l}\text { Existing additional and optimization of flood- } \\
\text { pump }\end{array}$ \\
\hline & $\begin{array}{l}\text { Regularly develop and repair irrigation } \\
\text { networks }\end{array}$ \\
\hline & River Normalization \\
\hline & $\begin{array}{l}\text { Repairing, dredging and deepening of drainage } \\
\text { channels }\end{array}$ \\
\hline & Existing bio pores \\
\hline & Existing rain harvesting \\
\hline \multirow{2}{*}{$\begin{array}{l}\text { Structural } \\
\text { Mitigation }\end{array}$} & Existing river embankments \\
\hline & Retrofitting social and public facilities \\
\hline \multirow{9}{*}{$\begin{array}{l}\text { Non-Structural } \\
\text { Mitigation }\end{array}$} & Critical land rehabilitation on to green space \\
\hline & Residential restriction in riverbanks \\
\hline & $\begin{array}{l}\text { Existing disaster management plan (before, } \\
\text { during, and after a disaster) }\end{array}$ \\
\hline & Implementing river zonation \\
\hline & $\begin{array}{l}\text { Reinforcing penalties on spatial planning } \\
\text { violators }\end{array}$ \\
\hline & Existing flood insurance \\
\hline & $\begin{array}{l}\text { Existing disaster preparedness community } \\
\text { (KSB) }\end{array}$ \\
\hline & $\begin{array}{l}\text { Involving multi-stakeholder in DRR strategies } \\
\text { (all quadrants) }\end{array}$ \\
\hline & $\begin{array}{l}\text { Existing transboundary cooperation on flood } \\
\text { DRR management plan }\end{array}$ \\
\hline \multirow[t]{3}{*}{ Awareness } & $\begin{array}{l}\text { Conducting trainings on in all flood DRR } \\
\text { phases }\end{array}$ \\
\hline & Joining trainings from another institution \\
\hline & $\begin{array}{l}\text { Regular schedule for training (at least twice a } \\
\text { year) }\end{array}$ \\
\hline \multirow[t]{4}{*}{ Preparedness } & Flood drill / simulation \\
\hline & Frequency of drill / simulation \\
\hline & SOP on evacuation plan \\
\hline & Existence of Sekolah Sungai (Riverian-School) \\
\hline \multirow[t]{3}{*}{$\begin{array}{l}\text { Early Warning } \\
\text { System }\end{array}$} & $\begin{array}{l}\text { Existing community based early warning } \\
\text { system }\end{array}$ \\
\hline & $\begin{array}{l}\text { Constant monitoring of flood early warning } \\
\text { system }\end{array}$ \\
\hline & Existing dissemination media \\
\hline \multirow{3}{*}{$\begin{array}{l}\text { Emergency } \\
\text { Response }\end{array}$} & Existing flood-shelter \\
\hline & Existing food and water backup system \\
\hline & Existing electricity backup system \\
\hline
\end{tabular}

Risk assessment maps are available in both Kebon Baru and Kampung Melayu. According to the survey, risk assessments have been done several times in Kebon Baru and Kampung Melayu. However, risk assessment maps are not available at all times due to poor data management. Based on the interview with the key interviewees, this issue relates to civil servants' rotation without passing their past and ongoing work to their colleagues or the new officer in charge. 
TABLE II

KEBON BARU AND KAMPUNG MELAYU FloOd Risk ManAGEMENT PERFORMANCE LEVEL

\begin{tabular}{lll}
\hline $\begin{array}{l}\text { Flood Risk } \\
\text { Management }\end{array}$ & \multicolumn{2}{l}{$\begin{array}{l}\text { Flood Risk Management } \\
\text { Performance (\%) }\end{array}$} \\
\cline { 2 - 3 } & Kebon Baru & $\begin{array}{l}\text { Kampung } \\
\text { Melayu }\end{array}$ \\
\hline Risk Assessment & 58.33 & 41.67 \\
Prevention & 85.71 & 71.43 \\
Structural Mitigation & 75.00 & 50.00 \\
Non-structural & 66.67 & 66.67 \\
Mitigation & & \\
Awareness & 83.33 & 83.33 \\
Preparedness & 62.50 & 50.00 \\
Early Warning & 100.00 & 100.00 \\
System & & 100.00 \\
Emergency Response & 100.00 & \\
\hline
\end{tabular}

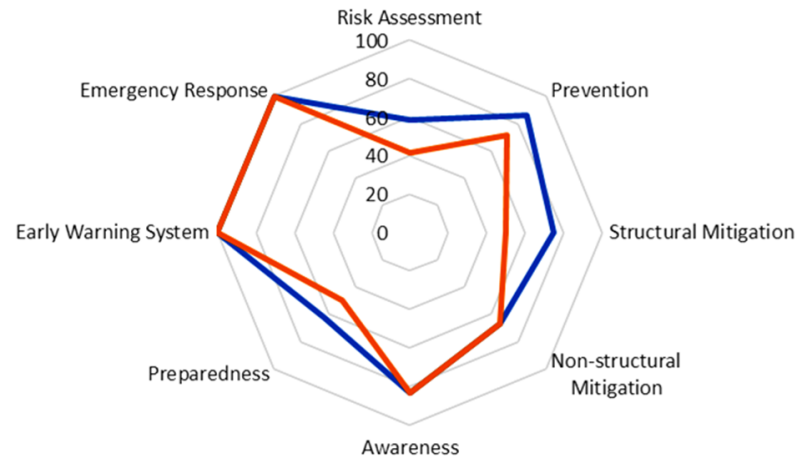

Kebon Baru Kampung Melayu

Fig. 5 Spider-web diagram of flood risk management performance in Kebon Baru and Kampung Melayu

In Indonesia, it is commonly accepted that civil servants are moved from departments to other departments every several years or even months (also known as rotation system). This culture will not be a problem if an effective communication and data management system between agencies and departments makes important information that can be passed along to the newly recruited officers after each rotation. Nevertheless, this issue can be easily tackled by improving civil servants' data literacy and management skills and an adequate data management system. Although it could be heavy work for the village-level government, the "One Data Policy" has been passed through Presidential Decree No. 39,2019 . This indicates the beginning of the transformation in all sectors in Indonesia in the next several years.

In Kampung Baru village, some structural mitigation measures are in places, such as river embankments and evacuation shelters' availability. In contrast, weaker structural mitigation has been in place in Kampung Melayu. Kampung Melayu has a great disadvantage in terms of its member's socio-economic situations. This is shown by the number of squatters living in non-permanent housings along the Ciliwung riverside in Kampung Melayu village (Fig. 6). This causes some challenges to local authorities on reinforcing river embankments or building other structures for flood mitigation.

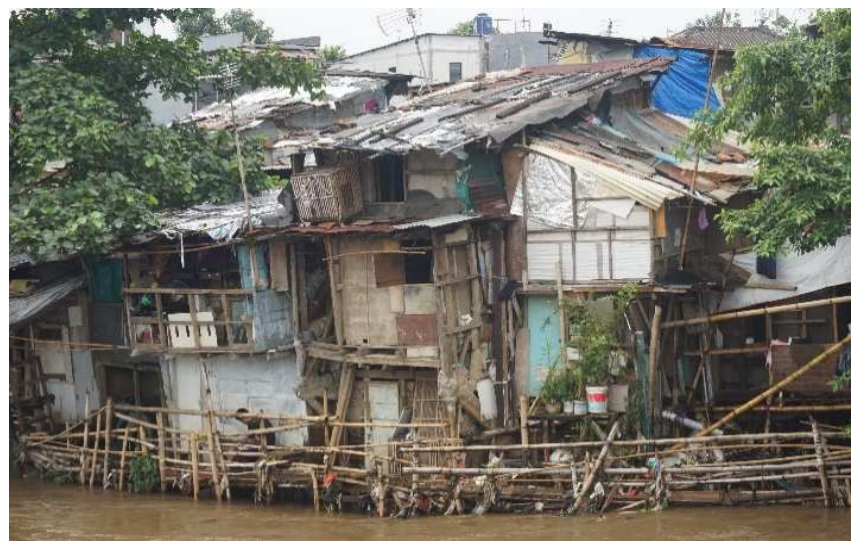

Fig. 6 Kampung Melayu squatters' housing along the Ciliwung River

In contrast, the flood early warning system and emergency response performance are very high in both villages. The flood early warning system in Jakarta Province mainly relies on real-time river watch supported by weather forecast information from the Meteorology and Climatology Office (BMKG). The EWS was found to perform effectively both in the upstream and downstream counterparts. Warning chain has also touched redundant, and various communication means and covers the last mile population. Still, this needs to be combined with an adequate level of awareness and preparedness to minimize loss and casualties.

In Kampung Melayu and Kebon Baru, the level of awareness and preparedness are fairly low considering the number of flood experiences they had. Even though simulation training and real flood practices could result in a higher level of awareness and preparedness, there is a lack of systematic learning tools for the community members to get better prepared for the coming floods. Unlike the flood early warning system and emergency response, organizations lack to strengthen community preparedness and awareness.

\section{B. Discussions}

Early Warning Systems (EWS) and Emergency Response (ER) are the two most well-established flood risk management elements in the two case study areas. In those aspects, there already is an effective synergy of local government, local champions, community members, and the private sector, which could be replicated in other areas of risk management. Still, there are challenges met in the way when managing flood risk in the prevention and mitigation stage, as the community members often have not set a common trajectory resilience goal by themselves [28].

Another aspect that has set the difference between the EWS and ER element from the others is the clear commando system from the local government until the very last mile in the community, at the time of floods. On the other hand, local champions have a prominent influence, an organization called "Mat Peci" in the case of the two case study areas, during the prevention and mitigation phases. There is also some evidence of Penta-helix collaboration, which involves community members, government, mass media, private sector, and scientists in those phases.

According to White [23], resilience-building requires some simple tools that help maintain constant improvement. The survey found a lack of preparedness measurement tools, even during an FGD that aimed to measure the communities' flood 
preparedness level. However, the FGD itself showed an initiative from the local government to collaborate with scientists in community capacity building, as the local organizers invited the authors' research team. However, there are some gaps to fill in order to have more effective collaboration.

In terms of monetary funding, there are multiple sources of donations for flood risk management in all phases (prevention, mitigation, preparedness, emergency response, and rehabilitation and reconstruction). Most of the donation comes from the national and local government, private sector through Corporate Service Responsibility (CSR), nongovernmental and charitable organizations. Meanwhile, the community members contribute mainly through nonmonetary contributions. There is still a strong willingness to help each other within the community, called "gotongroyong" in Bahasa Indonesia.

Despite the strong leadership from the grassroots "Mat Peci" community, there are other many potential community organizations that have not been actively engaged, such as the Religious Groups (DKM), Family Welfare Program (PKK), and Youth Organization (Karang Taruna) in the day-to-day practice of flood prevention, mitigation, and preparedness. These internal forces are among the most important factors to improve resilience level and should be promoted in the future, especially in conditions where structural mitigation does not favor the poor and marginal people.

Flood structures have been the primary tool used in Jakarta to reduced flood risk. However, evidence shows that unique socio-economic factors such as poverty and squatter issues in Jakarta conflict with the possibility of protection equity [18]. This was evidently shown as the riverbanks in Kampung Melayu, which are full of squatter housing, caused the local authority dilemma of building embankments that allow the squatters some "permance" or leaving them unprotected (Fig. 6).

It becomes more important to strengthen local social capital considering the low reliability of local government when building community disaster resilience. Thus, the community should not rely on village-level authorities as to the main actors since they might be replaced anytime; this goes back to the civil servant rotation system's standard practice. To have a controlled and observed improvement in community resilience, actions should be led by long-term or permanent actors, for example, by a community member or local champions.

There are some indications of collaboration between the national government and the grassroots community. Most national government programs are very general and thus only work in the community when translated to their local characteristics and needs. Therefore, collaborating with local organizations as a mediator should be practiced more in the future. This also works well because local champions who are also community member know the resources, strengths, and needs of their community better than the government. Volunteerism and activism should be promoted and appraised to increase community resilience.

Moreover, there is a need for mutual acknowledgment between community grassroots organizations and government authorities to accelerate and enhance community resilience building. There is a clear distinction between flood resilience programs promoted by grassroots organization "Mat Peci" and government institutions. Programs promoted by grassroots organizations are very community-driven, while government programs are a direct translation of national plans, making them less bespoke of the needs of a particular community. Government programs might cause unnecessary conflicts without engaging local champions, such as showcased in Betteridge and Webber [29].

\section{CONCLUSION}

Urban resilience assessment factors from various literature are used as a reference to conduct a community assessment in Kebon Baru and Kampung Melayu village in Jakarta, Indonesia. According to the assessment, the important factors for resilience in these urban villages are leadership in grassroots movements, community activism and volunteerism, and mutual acknowledgment between formal and informal risk reduction programs. Leadership is crucial to initiate major change within the community, while activism and volunteerism are important in driving the community into the desirable common vision. Synergizing formal and informal organizations are crucial to merge social capital and material resources as both are needed for building resilience. The current assessment indicates that promoting resilience in the cross-cutting sector at once is beneficial, namely climate change adaptation, business continuity, and disaster resilience. Lastly, this study showed that community resilience is a uniquely defined state of each community. Community resiliency needs to be built from within the community with support from the outside.

\section{ACKNOWLEDGMENT}

This study is funded under the 3-year research "Case for Support: Mitigating Hydro-meteorological Hazard Impacts through Transboundary River Management in the Ciliwung River Basin", specifically for Working Package 7 and 8 on developing resilient community systems through Integrated Flood Risk Early Warning System and End-to-end Flood Risk Management funded by bilateral cooperation between Indonesian Ministry of Research and Technology/National Research and Innovation Agency (Kementerian Riset dan Teknologi Republik Indonesia/BRIN) and UK Natural Environment Research Council (NERC).

\section{REFERENCES}

[1] H. P. Rahayu and S. Nasu, "Good Practices of Enhancement Early Warning System for High Populated Cities - A Case Study for Jakarta Flood," Soc. Soc. Manag. Syst., vol. 6, no. 1, Mar. 2010.

[2] M. K. V. Aalst, "The impacts of climate change on the risk of natural disasters," Disasters, vol. 30, no. 1, pp. 5-18, 2006, doi: 10.1111/j.1467-9523.2006.00303.x.

[3] T. Firman, I. M. Surbakti, I. C. Idroes, and H. A. Simarmata, "Potential climate-change related vulnerabilities in Jakarta: Challenges and current status," Habitat Int., vol. 35, no. 2, pp. 372-378, Apr. 2011, doi: 10.1016/j.habitatint.2010.11.011.

[4] M. Farid, H. Harumi Pusparani, M. Syahril Badri Kusuma, and S. Natasaputra, "Study on effectiveness of flood control based on risk level: case study of Kampung Melayu Village and Bukit Duri Village," MATEC Web Conf., vol. 101, p. 05003, 2017, doi: $10.1051 /$ matecconf/201710105003.

[5] C. Asdak, S. Supian, and Subiyanto, "Watershed management strategies for flood mitigation: A case study of Jakarta's flooding," Weather Clim. Extrem., vol. 21, pp. 117-122, Sep. 2018, doi: 10.1016/j.wace.2018.08.002. 
[6] H. Takagi, D. Fujii, M. Esteban, and X. Yi, "Effectiveness and Limitation of Coastal Dykes in Jakarta: The Need for Prioritizing Actions against Land Subsidence," Sustainability, vol. 9, no. 4, p. 619, Apr. 2017, doi: 10.3390/su9040619.

[7] Y. Budiyono, J. Aerts, J. Brinkman, M. A. Marfai, and P. Ward, "Flood risk assessment for delta mega-cities: a case study of Jakarta," Nat. Hazards, vol. 75, no. 1, pp. 389-413, Jan. 2015, doi: 10.1007/s11069014-1327-9.

[8] Y. Budiyono, J. C. J. H. Aerts, D. Tollenaar, and P. J. Ward, "River flood risk in Jakarta under scenarios of future change," Nat. Hazards Earth Syst. Sci., vol. 16, no. 3, pp. 757-774, Mar. 2016, doi: 10.5194/nhess-16-757-2016.

[9] P. Wijayanti, X. Zhu, P. Hellegers, Y. Budiyono, and E. C. van Ierland, "Estimation of river flood damages in Jakarta, Indonesia," Nat. Hazards, vol. 86, no. 3, pp. 1059-1079, Apr. 2017, doi: 10.1007/s11069-016-2730-1.

[10] R. Djalante, C. Holley, F. Thomalla, and M. Carnegie, "Pathways for adaptive and integrated disaster resilience," Nat. Hazards, vol. 69, no. 3, pp. 2105-2135, Dec. 2013, doi: 10.1007/s11069-013-0797-5.

[11] A. Susandi, D. R. Pratiwi, T. Suwarto, and M. Tamamadin, "Adaptive Behavior Assessment Based on Climate Change Event: Jakarta's Flood in 2007," Jan. 2011, p. 28.

[12] R. Djalante and F. Thomalla, "Disaster risk reduction and climate change adaptation in Indonesia: Institutional challange and opportunities for integration," Int. J. Disaster Resil. Built Environ., Jul. 2012, doi: 10.1108/17595901211245260.

[13] A. Bahadur and T. Tanner, "Transformational resilience thinking: putting people, power and politics at the heart of urban climate resilience," Environ. Urban., vol. 26, no. 1, pp. 200-214, Apr. 2014, doi: 10.1177/0956247814522154.

[14] I. Burton, S. Huq, B. Lim, O. Pilifosova, and E. L. Schipper, "From impacts assessment to adaptation priorities: the shaping of adaptation policy," Clim. Policy, vol. 2, no. 2-3, pp. 145-159, Jan. 2002, doi: 10.3763/cpol.2002.0217.

[15] A. H. Kwok, D. Paton, J. Becker, E. E. Hudson-Doyle, and D Johnston, "A bottom-up approach to developing a neighbourhoodbased resilience measurement framework," Disaster Prev. Manag. Int. $J$. , vol. 27, no. 2, pp. 255-270, Apr. 2018, doi: 10.1108/DPM-07-20170169 .

[16] D. Paton and D. Johnston, Eds., Disaster resilience: an integrated approach, 2nd ed. Illinois: Charles Thomas Publisher, Ltd., 2017.

[17] C. B. Field, T. Stocker, D. Qin, and V. Barros, Eds., "Managing the Risks of Extreme Events and Disasters to Advance Climate Change Adaptation," p. 594, 2012.
[18] P. Texier, "Floods in Jakarta: when the extreme reveals daily structural constraints and mismanagement," Disaster Prev. Manag. Int. J., vol. 17, no. 3, pp. 358-372, Jun. 2008, doi: 10.1108/09653560810887284.

[19] P. J. Ward, W. P. Pauw, M. W. van Buuren, and M. A. Marfai, "Governance of flood risk management in a time of climate change: the cases of Jakarta and Rotterdam," Environ. Polit., vol. 22, no. 3, pp. 518-536, May 2013, doi: 10.1080/09644016.2012.683155.

[20] BBWS Ciliwung Cisadane, "Trends in Flood Inundation in Jakarta Metropolitan Area," 2012.

[21] Dwirahmadi, Rutherford, Phung, and Chu, "Understanding the Operational Concept of a Flood-Resilient Urban Community in Jakarta, Indonesia, from the Perspectives of Disaster Risk Reduction, Climate Change Adaptation and Development Agencies," Int. J. Environ. Res. Public. Health, vol. 16, no. 20, p. 3993, Oct. 2019, doi: 10.3390/ijerph16203993.

[22] M. Pelling, K. O'Brien, and D. Matyas, "Adaptation and transformation," Clim. Change, vol. 133, no. 1, pp. 113-127, Nov. 2015, doi: 10.1007/s10584-014-1303-0.

[23] R. K. White, W. C. Edwards, A. Farrar, and M. J. Plodinec, "A Practical Approach to Building Resilience in America's Communities," Am. Behav. Sci., vol. 59, no. 2, pp. 200-219, Feb. 2015, doi: $10.1177 / 0002764214550296$.

[24] B. Smit, I. Burton, R. J. T. Klein, and R. Street, "The Science of Adaptation: A Framework for Assessment," Mitig. Adapt. Strateg. Glob. Change, vol. 4, p. 16, 1999.

[25] C. Polsky, R. Neff, and B. Yarnal, "Building comparable global change vulnerability assessments: The vulnerability scoping diagram," Glob. Environ. Change, vol. 17, no. 3-4, pp. 472-485, Aug. 2007, doi: 10.1016/j.gloenvcha.2007.01.005.

[26] L. Khoja, R. Schubert, and J. Joerin, "Social Resilience Indicators for Disaster Related Contexts: Literature Review," Singapore ETH Centre, 2020 .

[27] J.-S. Chou and J.-H. Wu, "Success factors of enhanced disaster resilience in urban community," Nat. Hazards, vol. 74, no. 2, pp. 661686, Nov. 2014, doi: 10.1007/s11069-014-1206-4.

[28] H. P. Rahayu, R. Haigh, D. Amaratunga, B. Kombaitan, D. Khoirunnisa, and V. Pradana, "A micro scale study of climate change adaptation and disaster risk reduction in coastal urban strategic planning for the Jakarta," Int. J. Disaster Resil. Built Environ., vol. 11, no. 1, pp. 119-133, Nov. 2019, doi: 10.1108/IJDRBE-10-2019-0073.

[29] B. Betteridge and S. Webber, "Everyday resilience, reworking, and resistance in North Jakarta's kampungs," Environ. Plan. E Nat. Space, vol. 2, no. 4, pp. 944-966, Dec. 2019, doi: $10.1177 / 2514848619853985$. 